Jacek Knopek*

\title{
Polish Jews in Africa in the interwar period
}

KeYwords: Jews, Africa, Poland, emigration

sŁowa kLuczowe: Żydzi, Afryka, Polska, emigracja

In the interwar period, in the Polish historiography for the years 1918-1939, an important issue was the migrations, which took on the form of the mass. They were, on the one hand, the aftermath of the economic emigration undertaken from the Polish lands even in the second half of the nineteenth century and the beginning of the twentieth century. World War I interrupted the process. On the other hand, the reasons must be sought among the political and military, economic and financial and cultural-religious situation of the country, which was reborn after years of annexation in $1918^{1}$. Apart from the unrestrained and spontaneous nature the migrations of people from the Polish lands at that time took on the regulated and planned form due to the policy of the state and institutions created especially for this purpose. They also exerted a certain influence on the form of exodus and its directions and strengthening the policy of emigration, as the overall activities of the state in terms of population migration. Due to the fact that Poland of the interwar period was a multi-ethnic country and national minorities accounted for a relatively large proportion of citizens, not only Poles emigrated. In the structures of state administration, they began to wonder over the possibility of discharging tensions between national groups with the immigration policy. One of the ethnic groups, which they devoted particular attention were the Jews who did not have their own country at the time, but many lived not only on Polish lands, but other European countries as well.

* Political scientist; Associate Professor at the Faculty of Political Science and International Studies at Nicolaus Copernicus University in Torun and the Faculty of Humanities of University of Technology in Koszalin. Mail: jknopek@wp.pl.

1 See: H. Janowska, Emigracja zarobkowa z Polski 1918-1939, Warszawa 1981. 
It is true that the Black Continent in the interwar period was the continent ${ }^{2}$, where the least number of inhabitants from the Polish lands went, but anyway migration from Polish territory to the areas in Africa took place. Polish citizens of Jewish faith occupied a special role among the migration movement ${ }^{3}$. So far this subject has not enjoyed more interest in the literature ${ }^{4}$, and hence the need for deeper analysis appeared. The main aim of this article is to show the numerical states of representatives of the Jewish community who moved from the Polish lands to Africa, further indication of the directions of migration, and to determine the role that Polish Jews acted in local environments. The main sources that were used to write this study were archival documents deposited in the Archives of New Files in Warsaw ${ }^{5}$ supported by the necessary bibliographic query.

Until the early twentieth century, the presence of the inhabitants of the Polish lands in Africa was indeed visible, but never took the form of mass migration. In the past, there were different groups of people who made their way to the Black Continent: the knights taking part in expeditions to the Holy Land, pilgrims travelling to the holy places, travelers, researchers and academics, missionaries, soldiers serving in the German colonial forces and the French Foreign Legion and the Navy of Western European countries, as well as economic migrants trying to gain a satisfactory financial situation. Among the above-mentioned professions, there was a group comprised of representatives of the Jewish Diaspora, who came to the African continent from the Vistula area or through other European countries. Nevertheless, one can distinguish among them some more characteristic people. The most significant was a representative of the Jewish community originating from Poznan, who was called Gaspar da Gama or

2 Black Continent in this article has been treated widely covering in the period the so-called Arab Africa in the north, black Africa across most of Africa and white Africa limited to the southern reaches of Africa. See: Africa environment outlook: past, present and future perspectives, Nairobi 2002.

3 Although there is no generally division of people according to ethnic structure in the ministerial documentation of this period, and diplomatic reports, but in this type of lists the column 'religion' or 'faith' was frequently used, therefore socio-ethnic divisions in this regard are much easier to carry out. It should be noted, however, that the Jewish diaspora, which derived from the Polish lands, had in most cases Polish citizenship, so some individuals and families went to the Polish diplomatic missions, mostly honorary consulates, at their invitation or asking for material assistance.

4 Among the authors of the Polish pointed out Arkadiusz Żukowski paid attention to emigration of Polish Jews on the Black Continent: Jews from the Polish lands in South Africa at the turn of the $19^{\text {th }}$ and $20^{\text {th }}$ century, "Bulletin of the Jewish Historical Institute" 1994/1995, No. 4/2, pp. 3744. Other researchers, including foreign ones, due to trace amounts and peripheral issues, did not devote much attention to this.

5 In the interwar period in the Black Continent Polish government appointed one legation of the RP based in Cairo and several honorary consulates, offices were located in centers where there were some Polish and of Polish origin communities. They were set up in North Africa (excluding Libya), French West Africa, the Union of South Africa and in Angola and Madagascar. 
Gaspar da India on the Iberian Peninsula ${ }^{6}$. In the second half of the nineteenth century and especially at the beginning of the twentieth century Jews made their way to Africa from the Russian Empire, which was the result of persecution and pogroms against the Jewish population, which at that time occurred successively there. Due to the fact that in Palestine it was not safe either, some Jewish families stopped in North Africa, especially in Egypt, waiting for the opportunity to continue their way to Jerusalem and other places known from the Bible. During World War I, when there were approx. 100-150 people with Polish roots on the $\mathrm{Nile}^{7}$, meetings of representatives of the Jewish community with Polish immigrants were held, and even an association having the character of a national-Polish committee was created ${ }^{8}$. Another region, where the Jews from the Russian occupation followed, was South Africa, where rich deposits of gold and diamonds were discovered, which began to attract not only trappers, but also artisans, merchants and traders who settled on the spot to support the local economic development ${ }^{9}$. Individuals and families of Jewish origin went also to other regions of the Black Continent settling in urban centers, serving mostly the role of the capital or the main administrative facilities. They were involved in petty trade and crafts, but educated people could be found in this group, such as doctors or engineers.

The end of World War I did not cause greater interest in the Black Land among the Polish citizens, including the Jewish community ${ }^{10}$. The reason for this was sometimes reluctance to admitting Jewish people. This situation particularly concerned the socalled Arab Africa, in which social religious conflicts were still alive. One of the entities in the area where the Jewish population was not welcome was - having greater political autonomy - Egypt. Nevertheless, with the end of the war several Jewish families came to Alexandria, joining the existing large Jewish community there. In the 20 s of the twentieth century, at least a dozen more families from the Vistula area arrived there, but some of them did not participate in the life of Polish or of Polish ori-

6 Gaspar da Gama or Gaspar da India (b. approx. 1450, d. Approx. 1510) - a Jewish traveler was born probably in the Polish Kingdom, in Poznan, naturalized in Portugal. As a sailor, he travelled between the Iberian Peninsula and India, sailing around the African continent and stopping along the way in the Portuguese trading posts.

7 Among the structures, the representatives of the Jewish community accounted for at least half of work force.

8 See: H. Kaczmarek, Polacy w Egipcie do 1914 roku, Szczecin 2008.

9 A. Żukowski, W kraju złota i diamentów: Polacy w Afryce Południowej XVI-XX w., Warszawa 1994, pp. 106 and following.

10 Apollonius Zarychta preparing reliable statistical and factual study on the Polish emigration noted that in the years 1926-19342336 people left from Poland for the African continent. On average in the period examined by him during the years 1918-1931, less than 200 Polish citizens reached the Black Continent annually. These values accounted for less than $1 \%$ of the total number of emigrants leaving the country. See: this same, Emigracja polska 1918-1931 i jej znaczenie dla państwa, Warszawa 1933, p. 35. 
gin communities, participating at the same time only in the religious structures of the Jewish faith ${ }^{11}$. In the mid-30s of the century, the Polish Legation in Cairo estimated the number of Polish citizens in this country maintaining irregular contacts with the local diplomatic post for approx. 150 people, half of them were the representatives of the Jewish faith. The second group of at least several hundred were Polish Jews who did not keep any contacts with the legation, and if they knew the Polish language, according to the diplomats, did not use it every day. The figures relating to the latter were only estimates, because the Legation knew of such people, however, due to the fact of merging their representatives in the local Jewish communities did not have reliable informants who could write down their personal data ${ }^{12}$. Despite this situation in 1933, the Polish Association of Charity was appointed on the initiative of the Polish Legation in Cairo that was supposed to continue the previous activities of associations of the First World War period. Among the several dozen members of the initiative group of this project, Polish citizens of the Jewish faith were mainly the leaders ${ }^{13}$. However, they were educated people from the Vistula areas and of better material status, who not having a regulated status of the state, did not want to break contacts with the Polish diplomats. Unfortunately, due to conflicts occurring within a small number of the Polish community in that country, the Association did not manifest greater activity and they decided to suspend it three years later ${ }^{14}$. The Jewish community also led the way in the Egyptian-Polish Chamber of Commerce, set-up in the second half of the 20s of the twentieth century, which since 1928 issued its own quarterly newsletter where announcements and advertisements of the local Polish community running their own business were placed ${ }^{15}$.

11 However, the Jewish community associated with the element of Polish and living in the country of pyramids They did attempt to establish a Polish-Egyptian diplomatic relations already in 1920. They turned to the Polish Ministry of Foreign Affairs with a request for the establishment of the Nile Polish consulate, which would represent the interests of Poles staying there. Central Archives of Modern Records, Polish Embassy in Washington, sygn. 2479, c. 16 and following. In 1926, when the official Polish-Egyptian diplomatic relations were established, at the request of Polish citizens of Jewish nationality consular department of the diplomatic mission was launched there. AAN in Warsaw, Ministry of Foreign Affairs (MSZ), sygn. 10824: the correspondence of Polish Embassy in Cairo in 1933.

12 The Polish Institute and Sikorski Museum in London, T. Korwin-Piotrowski's collection, sygn. KOL. 250: correspondence between T. Korwin-Piotrowski and Polish Embassy in Cairo.

13 The initiative group consisted of: dr Henryk Adelfang, Henryk Bernard, Mendel Bukszpan, Teodor Grawe, Wiktor Kurzweil, prof. Bogdan Richter, dr Ryszard Stankiewicz, Maksymilian Steinauer i dr Daniel Zalberg. AAN in Warsaw, MSZ, sygn. 10824: Société Polonaise de Bienfaisance du Caire, c. 13-27: Statuts. 1933.

14 AAN in Warsaw, MSZ, sygn. 10824: the correspondence of Polish Embassy in Cairo in

15 'Bulletin Trimestriel de la Chambre de Commerce Egypto-Polonaise du Caire' 1928, nrs $1-3$. 
Representatives of the Jewish community who were born in Poland were also in other regions of the so-called Arab Africa. In the interwar period, a small number of people of economic emigration appeared in the areas of the Maghreb, dominated by French colonial policy then. Throughout the period the Polish and of Polish origin civil groups - in relation to Morocco, Algeria and Tunisia - were estimated to be tens or hundreds of people ${ }^{16}$. For this reason, it was decided to launch their administrative centers, honorary consulates that could activate Polish foreign policy in this direction and at the same time take care of Polish citizens living there. These posts informed in their reports that at least half of the Polish and of Polish origin communities had been dominated by representatives of the Jewish faith, who most often treated ambivalently both Poland and promoted by the state patriotic values. More often representatives of these groups came to claim the aid or welfare payments, and far less likely to participate in the promotion of independence and patriotic actions. They reluctantly came to the consulates for registration; at most, they wanted to extend the validity of their passports or other identity documents ${ }^{17}$. The situation in the Maghreb was similar, therefore, to that of Egypt. The unclear state status of the community meant that they wanted to keep the base of the legalization of their stay, although they were aware of the fact that the leading institutions in this field were the French authorities. Hence, the Jewish community cared more about the correct establishing of contacts with representatives of the colonial administration, rather than Polish diplomats. In the situa-

16 A separate group of emigrants were those Polish citizens who were engaged in the ranks of the French Foreign Legion, which had its bases and stationed in Maghreb, especially in the territory of Algeria. The number of Polish soldiers in the ranks of the Foreign Legion can be estimated from several hundred to several thousand, depending on the specific years. The number of them increased in the period after World War I, when followed by demobilization of soldiers fighting on the front and in the years of the Great Depression, when seeing no other chance of finding employment emigrants enlisted to serve in the armed formations. From the few interviews or letters to the editors of Polish magazines, as well as the reports of the Polish Consulate in Marseille, which prompted this case, it follows that the Polish national minorities were represented in the Foreign Legion rather sparsely. This was also true among representatives of the Jewish faith, who would rather shun the service in its branches, but individuals also had their way. Because of their duties legionaries did not participate in meetings of the Polish community, because quartered in their units they served 5-year contracts. After the completion, they mostly travelled to France or Poland or renew their contracts for another 5 years. See: AAN in Warsaw, The Polish Consulate in Marseille, sygn. 852-84. Reports and consular correspondence from the years 1926-1937. It is difficult to say anything on the participation of Polish Jews in the Spanish Foreign Legion, organized on the French model, because the subject is even less was promoted in the scientific community. There were, according to various data, approx. 20-30 people coming from Polish every year. See: J. Białoskórski, Hiszpańska Legia Cudzoziemska, Warszawa 1939.

17 See: J. Knopek, Migracje Polaków do Afryki Pólnocnej w XX wieku, Bydgoszcz 2001, pp. 102 and following. 
tion of Polish Jews in the area, the former could give much more than Polish consuls could offer, especially that the latter had the honorary status ${ }^{18}$.

Another region of the Black Continent, in which Polish Jews indicated their presence, was South Africa. The first group reached this part of the world at the beginning of the 20s of the twentieth century, which was related to the rebirth of the Polish state. The second populous colony found there a place in the next decade and had a close relationship with the fact that Nazis came to power in Germany. Before World War II, the size of the Polish and of Polish origin communities in the Union of South Africa was estimated at 1,900 people, and this was by far the largest community in the Black Continent ${ }^{19}$. Apollonius Zarychta, by far the best versed in the subject of emigration of that period, also estimated that this group was dominated in $95 \%$ by people of the Jewish faith ${ }^{20}$. Long-term studies conducted by Arkadiusz Żukowski question the estimates of the first one, because both in the consular reports, as well as memoirs and newspaper articles, there are fairly numerous names not only Polish-like but also of the people of the Catholic faith ${ }^{21}$.

Nevertheless, a relatively large group of people of Jewish origin settled in the Union of South Africa. They maintained good and solid contacts with Polish diplomatic missions, called to life in the interwar period. It is no wonder that those Jews lived and ran business activity not only in the economic centers of South Africa, but cities, which where the honorary consulates were established. In Johannesburg, a Polish-Hebrew Association of Charity was set up in the first half of the 30s of the twentieth century. Its primary task was to provide assistance to Polish citizens coming to the South

18 How Jacek Knopek put this issue in the previous study: „In the regions of North African Polish Jews were a large part of emigrants, who were from 25 to $75 \%$ in each cluster; the most numerous clusters of Polish Jews occurred then in Egypt and Morocco; smaller in Tunisia and Algeria. They were usually craftsmen, brokers or holding small workshops and workplaces employing immediate family, or a few extra people. The Polish Jews in Egypt had the highest material status, where they were most often the commercial intermediaries; in the rest of North Africa they were engaged in craft or ran small shops. Raised: ibidem, p. 115.

19 AAN in Warsaw, MSZ, sygn. 9886: A. Zarychta, Dwudziestolecie emigracji z Polski 19181938, typescript, c. 59.

20 Ibidem. Some emigrants from South Africa informed the Polish diplomats of the fact that in the Union of South Africa a few or even several thousands of Jews associated with the Polish lands were staying, but most people did not feel the need of communication with them. If we could talk about such numbers, it was certainly about the German and Russian Jews, who during the partitions of Poland were staying in the Prussian and Russian partitions. This group identified mostly with the dominating community in the field and after the rebirth of the Polish state they migrated along with the German population into the Weimar Republic. After further migration to the South African, the population was subject to strong and rapid processes of assimilation, which was accompanied by an increase in satisfactory social status, especially the economic one.

21 A. Żukowski, $W$ kraju złota $i$ diamentów..., p. 125-153. This researcher also highlights a slightly different numerical information on the Polish and of Polish origin communities in this country. 
African lands. Polish Jews and British Jews descending from Polish lands were the main initiators and activists of this form of activity. A bunch of approx. 200 members of this socio-cultural initiative formed additionally a literary circle and a library with Polish books. They organized evening meetings related to Polish poetry or national holidays on 3 May and 11 November ${ }^{22}$. In Cape Town, in turn, outside the consulate, Polish Jews showed the activity in the established Federation of Polish Jews in the Cape Province ${ }^{23}$. One must also recognize that positively developed in the interwar period Polish-South African economic relations were based mainly on economic and financial connections of representatives of the Jewish faith, who often performed the functions of commercial agents promoting local goods imported from the Vistula areas.

Few groups of Polish Jews arrived at other regions of the Black Continent as well. A few or a few dozen families represented them. In West Africa, their presence fell on the main centers of the French administration, as Dakar and Abidjan. Only single families were present there. They did a small craftsman business or worked in the management of colonial areas ${ }^{24}$. In Central Africa, the presence of Polish Jews was linked to the Belgian Congo. E.g. in 1938 colonial administration hired 11 Polish citizens of Jewish faith to work in the area. However, the presence of this national group referred in the area to at least several dozen families who had arrived there earlier ${ }^{25}$. Despite being a small group, they left a lasting impression even in the contemporary political activity ${ }^{26}$. The problem of settlement in East Africa was similar. Polish Jews made their way there through the UK. According to Henryk Zins, who worked in this area as a university teacher after World War II, only a Jewish family of the Blocks reached a satisfactory social status in Kenya. In Nairobi and other cities, they launched a hotel

22 Ibidem, p. 136. As pointed out by Arkadiusz Zukowski one of the most active representatives of Polish-Jewish colony in Johannesburg was a patriotically disposed architect Jan Gliksman. This person in his youth took part in the Polish-Soviet War of 1920., And upon arrival at the Black Continent he eagerly identified with Polishness. Among other families maintaining contact with the Polishness the author mentioned: the Goński (earlier Gąska), Laubow, Levitz, Katelbach, Levin, Finder, Goryński and Kossowski.

${ }^{23}$ Ibidem, p. 137.

24 J. Knopek, Stosunki polsko-zachodnioafrykańskie, Toruń 2013, pp. 99 and following.

25 AAN in Warsaw, MSZ, sygn. 9764: Reports of the Polish Consulate in Antwerp for the period from October 1938 to March 1939.

26 Among the Congolese politicians, Leon Kengo wa Dondo (Leon Lubicz) has Polish roots, who for years has benn one of the most important figures in, located in the heart of Africa, the Democratic Republic of Congo. Kengo wa Dondo has already been the prime minister of the republic three times, and for several years has been sitting at the head of the local Senate. His father Michael Lubicz, as an aspiring doctor, came to Central Africa about 1933. In the Belgian Congo he healed and became involved in life with a representative of group of Tutsi. Leon Lubicz was their son that later - during the Africanization of the Congo - accepted the mother's name, which facilitated his political career. Nevertheless, as a Congolese newspaper pointed out, he distinguished with the lighter skin color and a different approach to life from the rest of tribesmen. Mentioned in: Polacy, zabierzcie swojego premiera!, www.wp.pl [access: 23.01.2012]. 
network, distinguishing by appearance and the level of services from the competition ${ }^{27}$. Although a specific ideological witch-hunt realized in Poland by the national democracy, there were no major settlements of Polish Jews in Madagascar and other African islands located in the Pacific Ocean. Only a family or single persons were present there. Slightly more families ran small businesses in Madagascar, supporting the local French administration and contacting with the Polish honor consulate ${ }^{28}$.

Characterizing the migration of Polish Jews to the African continent in the interwar period, you can have the impression that Polish and of Polish origin communities could exist there thanks to the presence of representatives of the Jewish faith. Such a specified thesis, of course, is not accurate, because on the Black Continent there were also planters, missionaries, sailors and soldiers serving in foreign-armed formations, among which the Jewish diaspora did not appear. However, it should be noted that the Polish Jews were a strong group of civilian economic immigration, dealing with crafts, engaged in the trade or the international trade brokering. The strongest and most enduring colony of Polish Jews proved to be that of southern Africa. In other regions, the communities were characterized by instability, changing location, or their situation resulted in further migration. Part of Polish Jews residing in North Africa intended to settle permanently in Palestine. Therefore, from the beginning of their stay in the area they seemed to be aware of the temporary nature of the settlement among the Arab population. In the remaining regions of the Black Continent, the Jewish population was dependent mainly on European colonial authorities. With the latter, they undertook therefore cooperation, seeing it as a chance to survive or to build adequate social and economic status.

\section{Bibliography}

Africa environment outlook: past, present and future perspectives, Nairobi 2002.

Białoskórski J., Hiszpańska Legia Cudzoziemska, Warszawa, 1939.

Bulletin Trimestriel de la Chambre de Commerce Egypto-Polonaise du Caire 1928, nrs 1-3.

Gołąbek S., Związki Polski i Polaków z Afryka do roku 1945, Warszawa-Łódź 1978.

Janowska H., Emigracja zarobkowa z Polski 1918-1939, Warszawa 1981.

Kaczmarek H., Polacy w Egipcie do 1914 roku, Szczecin 2008.

Knopek J., Migracje Polaków do Afryki Północnej w XX wieku, Bydgoszcz 2001.

Knopek J., Stosunki polsko-zachodnioafrykańskie, Toruń 2013

Polacy, zabierzcie swojego premiera!, www.wp.pl [access: 23.01.2012].

Zarychta A., Dwudziestolecie emigracji $z$ Polski 1918-1938, typescript

Zarychta A., Emigracja polska 1918-1931 i jej znaczenie dla państwa, Warszawa 1933.

Zins H., Polacy w Afryce Wschodniej, Lublin 1978.

27 H. Zins, Polacy w Afryce Wschodniej, Lublin 1978, pp. 30-35.

28 S. Gołąbek, Związki Polski i Polaków z Afryką do roku 1945, Warszawa-Łódź 1978, pp. 63 and following. 
Zukowski A., Jews from the Polish lands in South Africa at the turn of the 19th and 20th century, "Bulletin of the Jewish Historical Institute" 1994/1995, No. 4/2.

Żukowski A., W kraju złota i diamentów: Polacy w Afryce Południowej XVI-XX w., Warszawa 1994.

\section{Polish Jews in Africa in the interwar period}

ABSTRACT

The article presents the emigration of Polish Jewish community to the individual regions in Africa in the years 1918-1939. It is stated in it that Africa was not really popular among Polish immigrants. Before 1939 only about 4200 people who had Polish citizenship lived on this large continent. Polish Jews occupied an important place among the population.

Relatively the largest colonies of Polish Jews were then in North Africa (Egypt and the Maghreb) and in South Africa. Smaller ones were created in West, Central and East Africa. The wealthiest group of Polish Jews lived in Egypt and South Africa, where they were engaged in trade. In other regions, that group dealt with craft, had small shops or livied on hired labor.

Polish Jews were involved in the development of Polish and of Polish origin association life in Africa. They contributed also to establishing business contacts between Poland and African lands. Individuals received satisfactory material status and a good professional position or were engaged in political activities.

\section{Żydzi polscy w Afryce w okresie międzywojennym}

STRESZCZENIE

W artykule wskazuje się na emigrację społeczności żydowskiej z Polski do poszczególnych regionów afrykańskich w latach 1918-1939. Zaznaczono w nim, iż Afryka nie cieszyła się zbyt dużym zainteresowaniem wśród emigrantów polskich. Przed 1939 r. mieszkało na tym dużym kontynencie jedynie ok. 4200 osób mających polskie obywatelstwo. Wśród zbiorowości tej istotne miejsce zajmowali jednak Żydzi polscy.

Stosunkowo największe kolonie Żydów polskich istniały wówczas w Afryce Północnej (Egipt i Maghreb) oraz w Afryce Południowej. Mniejsze powstały w Afryce Zachodniej, Środkowej i Wschodniej. Najzamożniejsza grupa polskich Zydów zamieszkiwała Egipt i Afrykę Południową, gdzie zajmowała się handlem. W pozostałych regionach grupa ta trudniła się rzemiosłem, posiadała drobne sklepy bądź żyła z pracy najemnej.

Żydzi polscy brali udział w kształtowaniu polskiego i polonijnego życia stowarzyszeniowego w Afryce. Przyczynili się też do nawiązywania kontaktów gospodarczych między Polską a ziemiami afrykańskimi. Pojedyncze osoby uzyskały zadowalający status materialny oraz dobrą pozycję zawodową bądź zajęły się działalnością polityczną. 